\title{
Influence of European Culture on Washington Irving
}

\author{
Yang Zhao
}

Foreign Languages College, Beihua University, Jilin 132013, China.

\begin{abstract}
Keywords: Washington Irving, writing style, inheritance
\end{abstract}
\begin{abstract}
Washington Irving is an American writer who won international fame. The paper, by looking at the thick European Literature odor in Washington Irving's writing and relating to his personal experience together with the analysis of his production - "The Legend of Sleepy Hollow", attempts to make a study of the influence of European culture on Washington Irving's writing through illustration.
\end{abstract}

\section{Introduction}

Washington Irving is one of the earliest Romantic writers in America, who is known for his sketches, short stories and biographies. Irving is the first American writer who has attained international reputation. Absorbing the cream of European culture and literature, Irving has created his unique style that is fresh, natural, humorous and musical. With his short stories and success in many other fields, Irving has also made great contributions to the development of independent American literature. It was Irving who activated the potential of American literature and laid solid foundations for its future development. The Sketch Book of Geoffrey Crayon, Gent., published serially in the United States in 1819 and 1820, is considered as Irving's most successful work. It is also a great treasure in American literature.

\section{The citation of the British poems}

During Irving's time in England, Irving had read aloud literary works of famous poets and writers while he enjoyed beautiful landscape. Absorbing the cream of European culture and literature, Irving laid solid foundation for his creations. We can see that from the quotations of allusion in "The Legend of Sleepy Hollow". Most of its precise quotations which make the story full of wits are from the works of English poets-William Shakespeare and John Milton. These proper quotations play an important role in the story; they make the readers find everything new.

At first, the forward of "The Legend of Sleepy Hollow" quotes two sentences from the Castle of Indoence of the English poet-James Thomson:

"A pleasing land of drowsy head it was,

Of dreams that wave before the half-shut eye;

And of gay castles in the clouds that pass,

For ever flushing round a summer sky."

The two sentences only just indicate the meaning of the title - Sleepy Hollow. It showed us a lonely and dream fairyland that is isolated, attractive, and unpredicted. Irving provokes the readers' interests and notices at the beginning of the story. Seen from this, we can experience Irving's creative writing skills. In the third paragraph, in order to construct the mystery, the bewitchment, and the ghastfulness of the Sleepy Hollow, Irving gives us a depiction:

"The whole neighborhood abounds with local tales, haunted spots, and twilight superstitions; stars shoot and meteors glare oftener across the valley than in any other part of the country, and the nightmare, with her whole nine fold, seems to make it the favorite scene of her gambols." Here, Irving cites "and the nightmare, with her whole nine fold" from Shakespeare's King Lear. He successfully sets off an unreal atmosphere for us. 
Besides the depiction of the scene, Irving also cites the characters and the verses from the British poetry on delineating the characters in the story. He combines the quotations with the minute, humorous and vivid description and gives us lifelike characters. For example, in the eighth paragraph, Irving's portrayal of Crane's appearance bears a close resemblance to a crane's:

"He was tall, but exceedingly lank, with narrow shoulders, long arms and legs, hands that dangled a mile out of his sleeves, feet that might have served for shovels, and his whole frame most loosely hung together. His head was small, and flat at top, with huge ears, large green glassy eyes, and a long snipe nose, so that it looked like a weather-cock, perched upon his spindle neck, to tell which way the wind blew." Then he compares Crane to "the genius of famine", by this time, Irving has lively embodied Crane's ridiculous character and vivid individuality.

In the ninth paragraph, subsequently, Irving quotes "Spare the rod and spoil the child" from Hudbras of the English poet-Samuel Butler to show us Crane's teaching plan, that is strict and cruel, which is just corresponding to Crane's appearance portrait. But in the twelfth paragraph, we can find out Crane's another character by Irving's writing: "He found favor in the eyes of the mothers, by petting the children, particularly the youngest; and like the lion bold, which whilom so magnanimously the lamb did hold, he would sit with a child on one knee, and rock a cradle with his foot for whole hours together."

Irving quotes "like the lion bold which whilom so magnanimously the lamb did hold" from The Lost Land, comparing Crane to lion together with comparing the children to the lamb. From this quotation, we can get that Crane's behavior is sham, and we also can easily find out what Crane is up to, that is to curry favor with the children's mother.

In the evening, Crane finds his own interest in his awful and nasal voice melody: "and the good people of Sleepy Hollow, as they sat by their doors of an evening, were often filled with awe, at hearing his nasal melody 'in linked sweetness long drawn out', floating from the distant hill or along the dusky road.” Here, Irving quotes “in linked sweetness long drawn out” from Milton's work. Till now, Crane’s awful, lively, ridiculous and even pitiable character is completely embodied. In the whole story, Irving's citations of British poetry exceed ten times, naturally and properly, just like bringing life to an article by adding a few words to it. The citations do not only fuse the preface and plots but also make the story lively and effective.

\section{The quotations of Ancient Greek and Rome Myth}

Besides the British poetry, Irving quotes a large number of characters and plots from the Ancient Greece and Roman myth as well. Most of these citations are used to delineate the figures' dispositions and their outward appearances.

Myth is one of the most precious treasures of human beings, and it is the resource of the western culture. Myth is also firmly connected with literature. As is known to all, it is the British literature that receives the maximum influence of the Greece and Roman myth. The Ancient Greece and Roman myth rely on the handing down of Homer - The Iliad and The Odyssey in words from generation to generation, and it was enriched and developed continuously by the poets and the play writers in ancient Greece and ancient Rome. Since the Renaissance in sixteenth century, some English humanities as More and Shakespeare, had sucked nutrition out of the ancient literature, thus stimulated their writing inspirations, Irving spent most of his seventeen years in England, no doubt he was familiar with the local conditions and customs in England, hence his literary works were subconsciously affected by the Ancient Greece and Roman myth. According to the vigorous characters in the Ancient Greece and Roman myth which are close to the actuality, or going beyond the actuality, alone with their everlasting sense of beauty, they have always been the materials for the scholars. Irving's citations in "The Legend of Sleepy Hollow" give the finishing touch to the figurative characters. It also reflects Irving has a large stork of information, and reached perfection in metonymy. For example, there is a description in the twenty-sixth paragraph:

"He was broad-shouldered and double-jointed, with short curly black hair, and a bluff, but not unpleasant countenance, having a mingled air of fun and arrogance. From his Herculean frame and great powers of limb, he had received the nickname of BROM BONES, by which he was 
universally known.”

It is a period for the renaissance of myth between $19^{\text {th }}$ and $20^{\text {th }}$ century. Just like many other writers, Irving quoted the ancient fairy tales and ceremonies that were used to be regarded as running counter to truth and science; moreover he links them with the characters and the plots which were created in his works. Like this, Irving expresses his thoughts thoroughly, further more; he deeply revealed the theme of his works.

\section{The exertion of Gothic depiction}

The Gothic novel is an English literary genre, which can be said to have been born in the second half of the $18^{\text {th }}$ century. It was invented almost single-handedly by Horace Walpole, whose The Castle of Otranto (1764) contains essentially all the elements that constitute the genre. It is the predecessor to modern horror fiction and above all it has led to the common definition of Gothic as being connected to the dark and horrific. It acts, however, as a reaction against the rigidity and formality of other forms of Romantic literature. It leads habitually with darkness and horror. Not a few contemporary and modern English and American writers are profoundly influenced by it, many first-class writers employ some devices of Gothicism in their writings. Irving's writing was also influenced by it. We can see the influence in "The Legend of Sleepy Hollow”. Prominent features of gothic novels included terror, mystery, the supernatural, doom, decay, old buildings with ghosts in them, madness, hereditary curses etc.

There is great Gothic color on the plot of "The Legend of Sleepy Hollow". Often the Gothic novels' plot itself is built around a mystery, such as unknown parentage, a disappearance, or some other inexplicable event. The Headless Horseman represents the mysterious energies which can surpass the nature. According to the rumors of the local inhabitants, the Headless Horseman was an apparition of a decapitated Hessian solider that haunted the area. Before his death, he had been employed by the British, and then his head was blasted away by the bomb in the American War of Independence, and his corpse was buried in the graveyard. Therefore, when Ichabod met the Headless Horseman in the pitch-dark groove, Ichabod saw the Headless Horseman rising in his stirrups and in the very act of hurling his head at him-this plot pushes the terror and the fear to a new height, and gives the readers shivers.

The background of "The Legend of Sleepy Hollow" also contains the Gothic's time-honored mysterious color. America had got its victory in the War of Independence when the story happened, the ghosts like the Headless Horseman was still pacing up and down in this land. Ichabod was refused by his sweetheart and became intoxicated; when Ichabod was on his way home, the night grew darker and darker; the stars seemed to sink deeper in the sky, and driving clouds occasionally hid them from his sight. The elements like fearful tree, oaks, chestnuts, bridge, and the graveyard make the story shrouded in the ghostly atmosphere.

\section{Summary}

Irving's contribution to American literature is unique in more than one way. He was the first American writer of imaginative literature to gain international fame. Irving gave his works distinctive American flavor, "Rip Van Winkle” or "The Legend of Sleepy Hol1ow", however exotic these stories are among the treasures of the American language and culture. These two stories easily trigger off American imagination with their focus on American subjects, American landscape, and, in Irving's case, the legends of the Hudson River region of America. It is not the sketches about Europe but the tales about America that made Washington Irving a household word and his fame enduring. He was father of American short stories. Though most of Irving's subject matter are borrowed heavily from European sources, which are chiefly Germanic, and his writings were greatly influenced by European literature, Irving's relationship with Europe in terms of his literary imagination can hardly be ignored considering his success both abroad and at home. 


\section{References}

[1] Roth, Martin, Comedy and America: The Lost World of Washington Irving, Kennikat Press, 1976.

[2] Rubinstein, Annette T., American Literature Root and Flower, Foreign Language Teaching and Research Press, 1998.

[3] Washington Irving, “The Legend of Sleepy Hollow”, Qingdao Publishing House, 2003.

[4] Chang Yaoxin, A Survey of American Literature (The $2^{\text {nd }}$ edition), Nankai University Press, 2004.

[5] HuaQuankun, Chen Zhengfa, A Dictionary of English Allusions, The Commercial Press, 2001. 